\title{
Analysis of Legal Regulations and Proposed Changes in Definition of Contour of Building in Real Estate Cadastre**
}

\begin{abstract}
This paper analyzes the legal regulations related to cartography and surveying with regard to the building structures entered into the real estate cadastral database. Particular attention has been paid to the contour of a building structure in the register of land and buildings, and to one of the descriptive attributes - the development area. Under the current laws, the development area results directly from the contour of a building structure.

The thesis of this paper is that the current manner of defining the contour of a building and the resulting development area do not reflect the factual status of the building in the field. In order to verify the above thesis, examples of various building structures have been provided that reveal flaws in the definitions. The result is a lack of uniformity in the collected cadastral data in the database of the real estate cadastre of Poland. The consequences of the definitions that are currently binding also include limited possibilities when using real estate cadastral data for economic and spatial planning as well as assessing taxes and benefits.

Based on an analysis of the current legal acts and examples of the existing building structures, the author formulated proposals for a definition of the contour of a building structure and its development area.
\end{abstract}

Keywords: building structure, real estate cadastre, register of building structures, contour of building structure, development area, spatial data

* AGH University of Science and Technology, Faculty of Mining Surveying and Environmental Engineering, Krakow, Poland

** This work has been done as a part of scientific research carried out in the Department of Integrated Geodesy and Cartography 11.11.150.444 


\section{Introduction}

The investment process involving the construction of a residential building requires active participation of a surveyor at each stage of its implementation. Surveying works are already necessary at the stage of preparing a map for design purposes, then with setting out a building based on a construction design and servicing a construction site, then with the as-built measurements at the final stage; and all of these activities are crowned with entering "the building" into the database of the real estate cadastre.

According to Polish legislation pursuant to Art. 21 section 1 of the Geodetic and Cartographic Law [17], the data contained in the real estate cadastre forms the basis for many other fields of administrative and economic activities in Poland (Fig. 1). In addition, as provided for in Art. 21 section 2 of the Geodetic and Cartographic Law, bodies and organizational units performing the tasks referred to in Section 1 cooperate with the authorities of the Geodetic and Cartographic Service on establishing and financing the system of access and exchange of data between the register of land and buildings as well as the cadastral or public records maintained by these bodies and organizational units. The need for data uniformity, its relevance, consistency in its definition, and harmonization follow from the above provisions in order to be exchanged and made available so they can be used in the aforementioned fields of the economy.

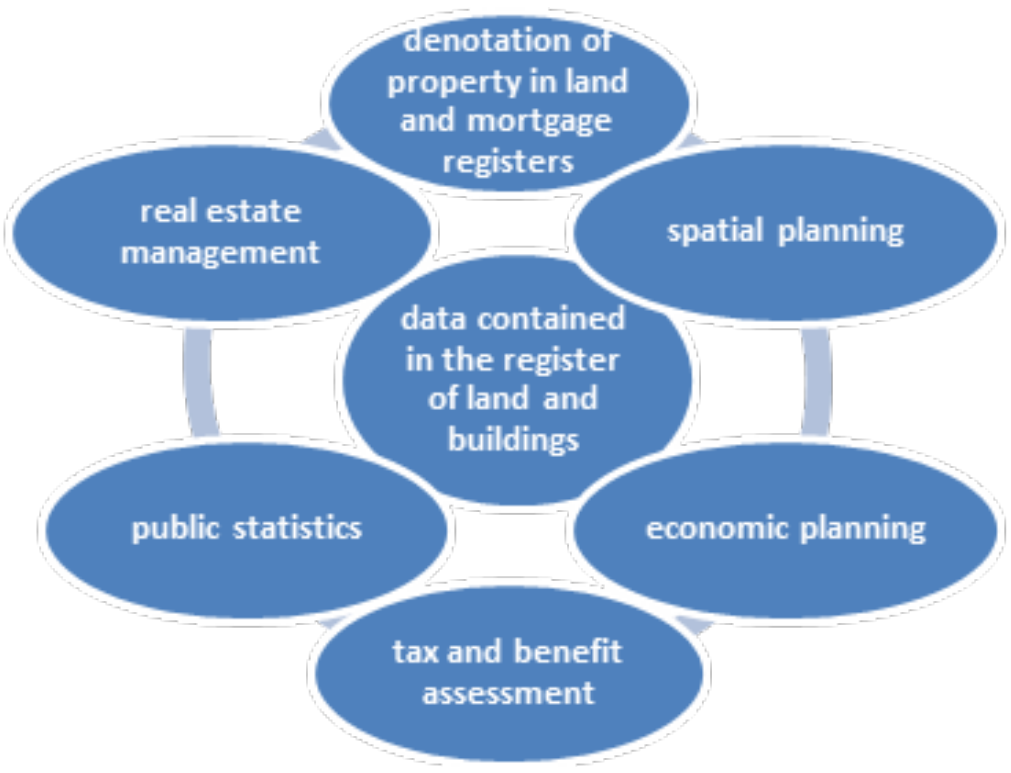

Fig. 1. Cadastral data as basis for other fields of economy 
At various stages of surveying work as well as in the works related to updating the cadastral database (either via its current updating or in the process of modernizing the register of land or buildings), the surveyor must comply with the definition of the contour of a building in their work. However, when studying "the building," it is not possible to be restricted to its contour only. It should be borne in mind that a building is not just its contour existing in the database of the register of land and buildings. Other components associated with the building that are objects of this register yet entered there as separate building structures despite being related to "the building" in terms of its contour (such as blocks of the building structure or elements permanently attached to it, such as a terrace, porch, vestibule, staircase, support, ramp, entrance to the underground, wheelchair ramp for the disabled) constitute the whole.

Already at this point, it is necessary to emphasize the logical and semantic inconsistency between the definitions in the regulation on the Register of Land and Buildings [25] and the regulation in the Database of Topographic Objects and the base map [28]. In the regulation on the Register of Land and Buildings, the contour of a building is its essential element (whose definition is broadly described there). However, the contour of a building does not have its cartographic representation in the regulation in the Database of Topographic Objects and the base map, as it does not exist there at all. Instead, the term that is used there is the outline (Fig. 2).

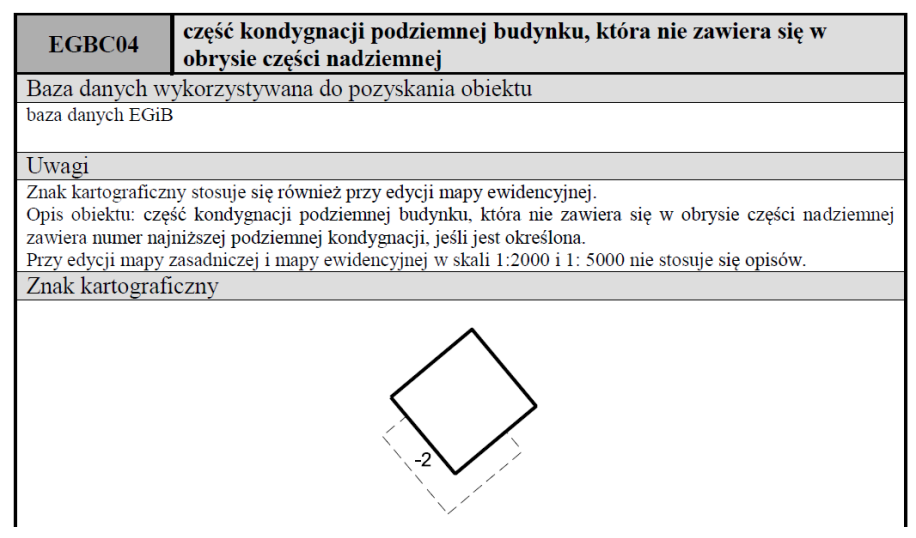

Fig. 2. Contour of building from Register of Land and Buildings, called outline in regulation in Database of Topographic Objects

Source: Regulation in Database of Topographic Objects, 2015

The definition of the contour of a building was formulated in $\S 63$ of the Register of Land and Buildings, which entered into force in 2001 in its original version and then was subsequently amended twice: in 2013 and 2015. The definition of the contour changed with each amendment; now, it is the third version over the past 
17 years in Poland. As a result, the same building can be represented in a substantially different cartographic form both in the cadastral map and base map (depending on the version of the regulation under which it was visualized) [5].

The second important attribute that follows directly from the contour of a building is defined as the development area of the building. According to $\$ 63$ Section 2 of the regulation on the Register of Land and Buildings, its size is closely related to the contour of the building: "The development area of a building is understood as the area of the geometric figure defined by its contour [...]." And due to the change in the definition of the contour of a building, the value of the development area of a building also evolves in the real estate cadastre. This is an important attribute of a building in the investment process, since it is necessary both at the planning stage of the development area (the plot ratio) and at the stage of the architectural and construction design of the specific construction project (as well as for the as-built surveys and determining the conformity of the investment with the design) [13].

Currently, there are various surveying technologies performed both from high altitudes and from unmanned aerial vehicles $[12,16]$. These range from classical tacheometric surveys through RTK GPS satellite surveys to laser scanning or photogrammetric surveys. Each of these surveys can result in very-high accuracy in determining the coordinates of the measured point. If this point - measurement terrain detail - is the corner of a building structure that, together with the other corners, is to define the contour of a building, then it should be remembered that, as a detail of the first-order accuracy, it should be determined with an accuracy of $0.10 \mathrm{~m}$ to the nearest points of the horizontal geodetic control and measurement control [27]. With a view to such high precision of the measuring technologies that surveyors can use today in their work, the problem does not concern with which instruments to measure in order to perform surveys with the required measurement accuracy but rather what to measure to obtain the contour of a building and the resulting development area that would be uniform across the whole country. Thus, the definition of the contour of a building should be analyzed (and amended in the end) to eliminate the existing errors and inaccuracies and, above all, the possibilities of different interpretations of the law today. Such an analysis and proposal of an amendment to the provisions are included in this article.

\section{Materials and Methods}

\subsection{Analysis of Legal Bases for Register of Land and Buildings in Poland}

According to the legislation on the real estate cadastre in Poland, after World War II (theoretically since 1947), buildings should exist in the cadastral survey according to the decree on the cadastre of land and buildings [20]. In subsequent 
decrees and orders [21, 22], buildings were treated in various ways, but with the tendency to limit information on them only on the cadastral map. Only the Register of Land and Buildings of December 17, 1996 [23] in \$28.1 introduced a list of buildings' cadastral and descriptive data. As far as the definition of the building is concerned, the regulation referred to the provisions of the act of July 7, $1994-$ the Construction Law [18]. The 1996 regulation did not contain the definition of the contour of a building. In the next regulation on the Register of Land and Buildings of March 29, 2001, the concept of the contour of a building was introduced. At the same time, the development area of a building was linked to its contour. However, it should be emphasized that both the definition of the contour and the definition of the development area changed each time during subsequent amendments to this regulation [15]. After a review of the original legislation and subsequent versions of the regulation: of 2001 (and after the subsequent amendments in 2013 and 2015), a summary of the structural elements of a building defining its contour was made (as presented in Table 1).

Table 1. Structural elements defining contour of building according to provisions of regulation on Register of Land and Buildings

\begin{tabular}{|c|c|c|}
\hline \multicolumn{3}{|c|}{ Regulation on the Register of Land and Buildings } \\
\hline $\begin{array}{c}\text { Regulation of } 2001 \\
\S 63, \text { section } 1 \text {, clause } 3 \text { ) }\end{array}$ & $\begin{array}{l}\text { Regulation of } 2013 \\
\S 63 \text {, sections } 1 \mathrm{a}-1 \mathrm{c}\end{array}$ & $\begin{array}{l}\text { Regulation of } 2015 \\
\S 63 \text {, sections } 1 \mathrm{a}-1 \mathrm{~b}\end{array}$ \\
\hline $\begin{array}{l}\text { the outer planes of the outer } \\
\text { walls of the building's ground } \\
\text { floor }\end{array}$ & $\begin{array}{l}\text { 1a. the outer walls } \\
\text { of the building }\end{array}$ & $\begin{array}{l}\text { 1a. the outer walls } \\
\text { of the building }\end{array}$ \\
\hline- & $\begin{array}{l}\text { 1b. if the foundation of the } \\
\text { building intersects with the sur- } \\
\text { face of the ground - the outer } \\
\text { edges of the foundation }\end{array}$ & $\begin{array}{l}\text { 1b. If the foundation wall of } \\
\text { the building intersects with } \\
\text { the surface of the ground - the } \\
\text { outer edges of the building's } \\
\text { walls that are based on these } \\
\text { foundation walls }\end{array}$ \\
\hline $\begin{array}{l}\text { if the story is based on pillars } \\
\text { - the outer walls of the story } \\
\text { based on these pillars }\end{array}$ & $\begin{array}{c}\text { 1b. if the story is based on } \\
\text { pillars - the outer edges of the } \\
\text { pillars }\end{array}$ & $\begin{array}{l}\text { 1b. if the story is based on } \\
\text { pillars - the outer edges of the } \\
\text { building's walls that are based } \\
\text { on these pillars }\end{array}$ \\
\hline- & - & $\begin{array}{l}\text { 1b. if the roof is based on pillars } \\
\text { - the outer edges of the roof }\end{array}$ \\
\hline- & $\begin{array}{c}\text { 1c. if there are underground } \\
\text { floors only - the outer edges } \\
\text { of that building (underground } \\
\text { ones) }\end{array}$ & - \\
\hline \multicolumn{3}{|c|}{ Definition of the development area of a building } \\
\hline $\begin{array}{l}\text { The development area shall be } \\
\text { understood as the surface area } \\
\text { of the geometric figure defined } \\
\text { by the contour referred to in } \\
\text { Section } 1 \text { Clause } 3\end{array}$ & $\begin{array}{l}\text { The development area shall be } \\
\text { understood as the surface area } \\
\text { of the geometric figure defined } \\
\text { by the contour of a building } \\
\text { referred to in Sections 1a-1c }\end{array}$ & $\begin{array}{l}\text { The development area shall be } \\
\text { understood as the surface area } \\
\text { of the geometric figure defined } \\
\text { by the contour of a building } \\
\text { referred to in Sections 1a and } 1 \mathrm{~b}\end{array}$ \\
\hline
\end{tabular}


In the commentary on Table 1, several cases of buildings will be presented (Figs. 3-12). Based on the photographs, the provisions of the regulation regarding the contour of a building will be analyzed. This will allow us to demonstrate discrepancies in the interpretation of this term that have occurred among surveyors and in the geodetic administration together with the amendment to the regulation on the Register of Land and Buildings (especially the provisions contained in $\S 63$ of the regulation). It will also justify the need to amend the legislation in this respect.

The technological process of erecting a building determines that the foundation wall of the building intersects with the surface of the ground [4]. Therefore, as this is most-common in practice, such a case should be mentioned first in the definition of the contour and not second (which is the case right now) as if it were some special case ( $\$ 63.1 \mathrm{a}$ and $\S 63.1 \mathrm{~b}$. of the regulation). This means that the contour of a building should be determined by its ground floor whenever it is visible above the ground level (and constitutes the foundation wall). This is especially important, because walls based on foundation walls are not always extensions of them. Sometimes, a ground floor has no vertical walls, and these walls are slanted in many buildings in the historical centers of southern Polish cities; for example, in Krakow in the Małopolska province or in Jarosław in the Podkarpacie province (photographs in Figs. 3 and 4).
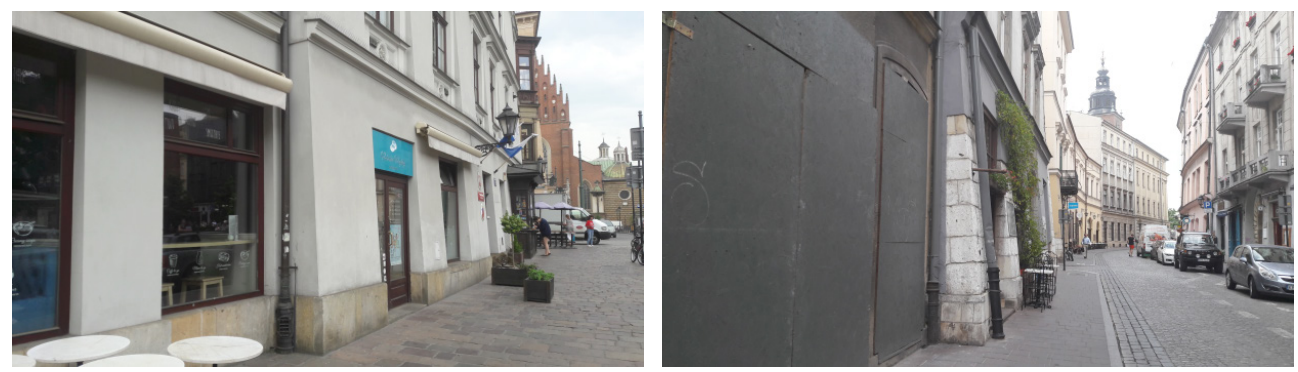

Fig. 3. Buildings with slanted walls of ground floor (phot. M. Buśko)
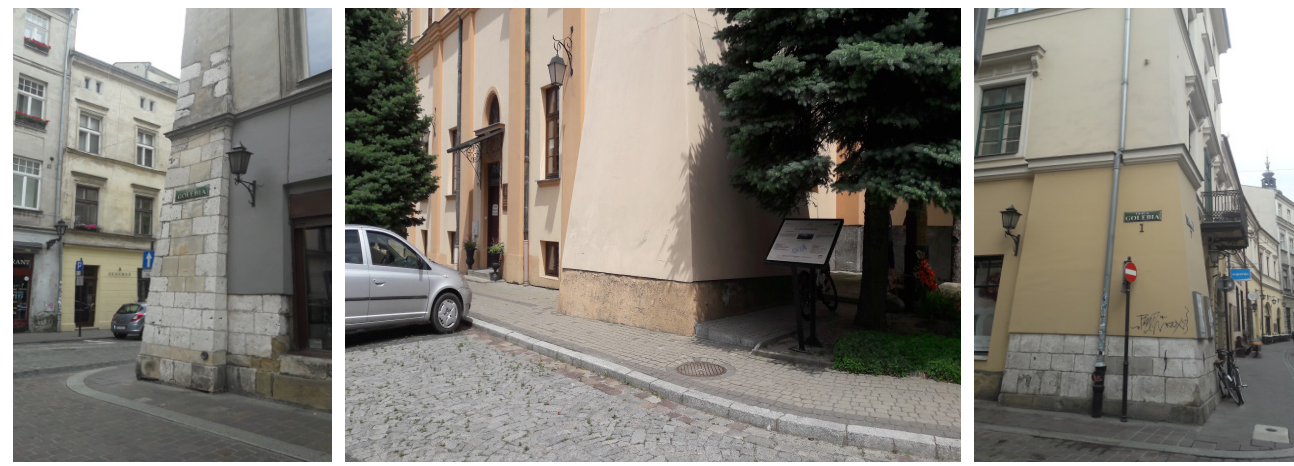

Fig. 4. Buildings with slanted walls of ground floor (phot. M. Buśko) 
Another example in favor of the concept that foundation walls should form the contour of a building is as follows: both the foundation walls and walls of the building's aboveground stories are vertical, but the latter are not extensions of the foundation walls (as illustrated in Figure 5). The contour of such a building determined by the foundation walls will, therefore, be larger than the contour that would be determined by the vertical projection of the higher stories. Such buildings are very common.
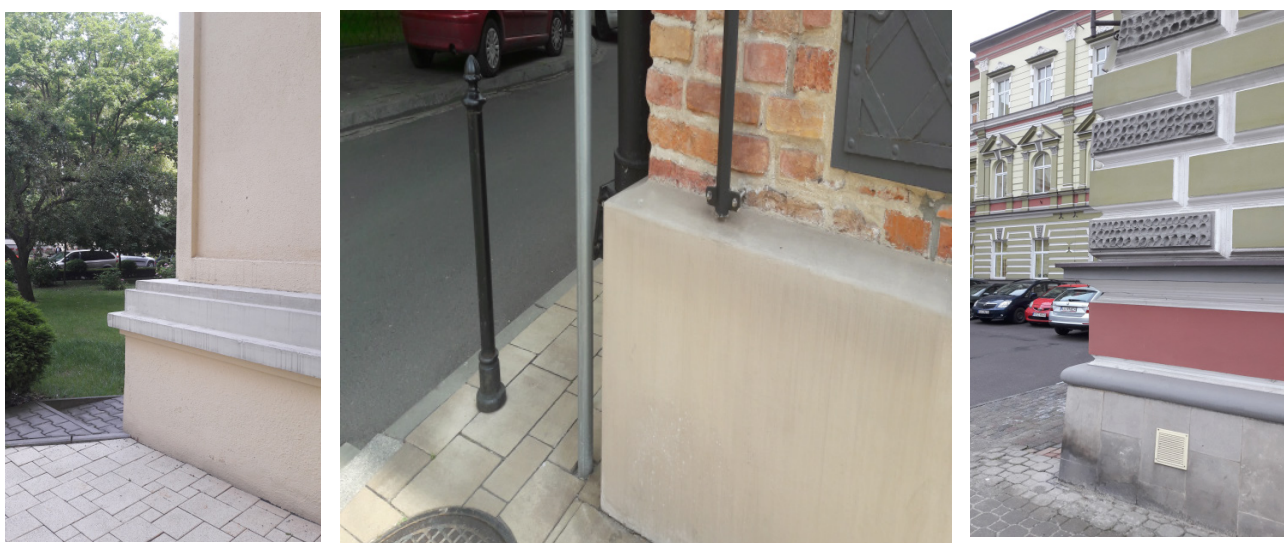

Fig. 5. Foundation wall creates contour larger than vertical projection of walls of higher story (phot. M. Buśko)

Naturally, there are also situations opposite to those demonstrated in Figure 5. The thermal insulation of a building makes the walls of its higher stories protrude beyond the surface of the foundation walls; i.e., beyond the ground floor of the building (Fig. 6).
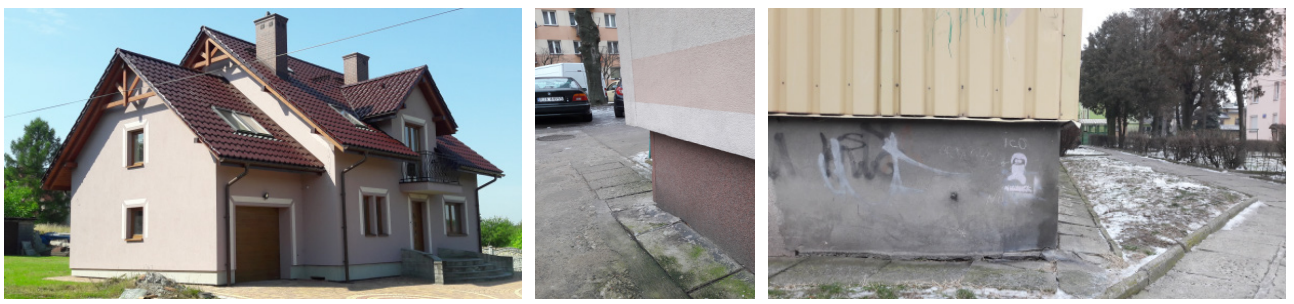

Fig. 6. Façade after thermal insulation creates contour greater than outline of building's ground floor (phot. M. Buśko)

In these cases (Fig. 6), however, the requirement of uniformity and consistency of the cadastral database should not be forgotten. In the Polish legislation regarding registers, there is the concept of a block of a building structure. If we assume that this is that part that is not included in its contour and, at the same time, we are aware of 
the acceptable measurement error of the building's turn point (which is $0.10 \mathrm{~m}$ in Poland with reference to the control). Then the facedes protruding beyond the contour of a building can be treated in two ways:

- if the vertical projection of the facade of the higher story deviates from the contour by more than $0.10 \mathrm{~m}$, then it should be entered into the database as a block of the building structure;

- if the discrepancy between the facade of the higher stories and the contour defined by its ground floor is less than or equal to $0.10 \mathrm{~m}$, then this detail shall be generalized, and the contour conforming to its ground floor shall remain.

A block that is an object in the database will be used primarily to present overhangs in buildings. Unfortunately, under the present legal situation in Poland, some overhangs are part of the contour of a building are included and others (even those of the same size) not. This is due to the fact that, in the Polish legislation, overhangs supported by pillars are part of the contour while overhangs that are not supported by pillars are not $(\S 63.1 b)$ - examples are depicted in Figures 7 and 8 .
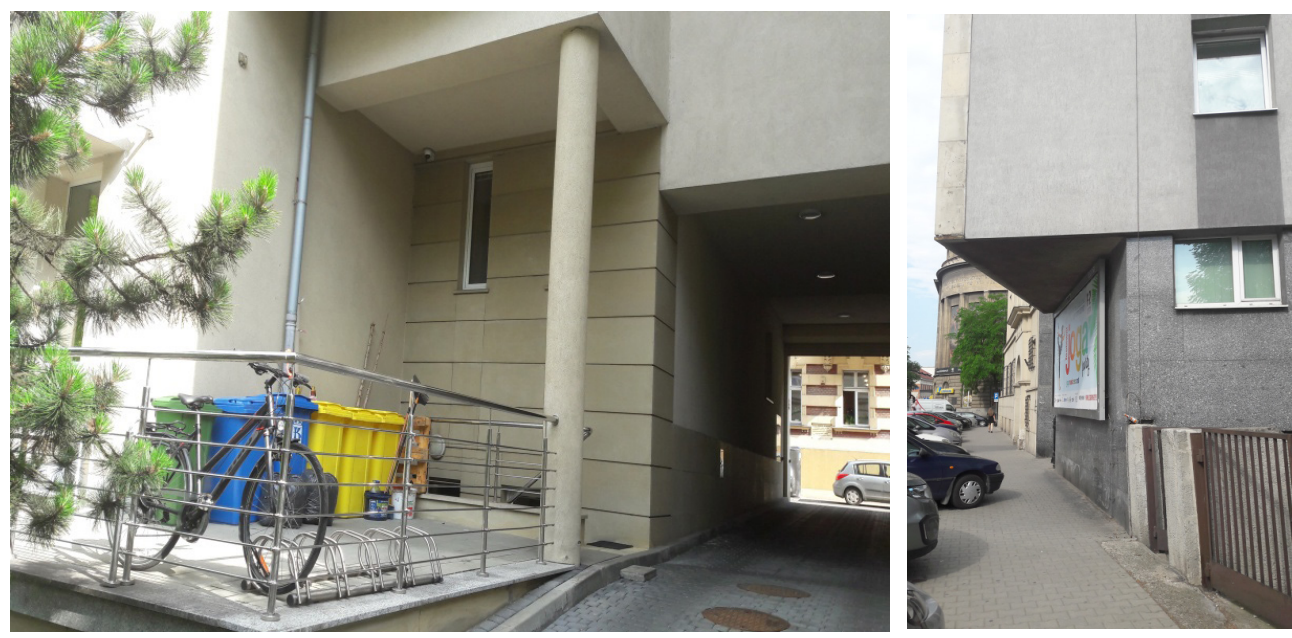

Fig. 7. Overhang of building supported by pillar and overhang not supported by pillar (phot. M. Buśko)

It should be emphasized that it is not reasonable if some overhangs are included in the contour of a building while other overhangs (even those of the same size) are not (Fig. 8). Overhangs of building structures should form blocks regardless of the fact of whether or not they are supported by pillars. Pillars are denoted in the Database of Topographic Objects with a separate cartographic symbol, and this fact should not affect the database of the real estate cadastre. 

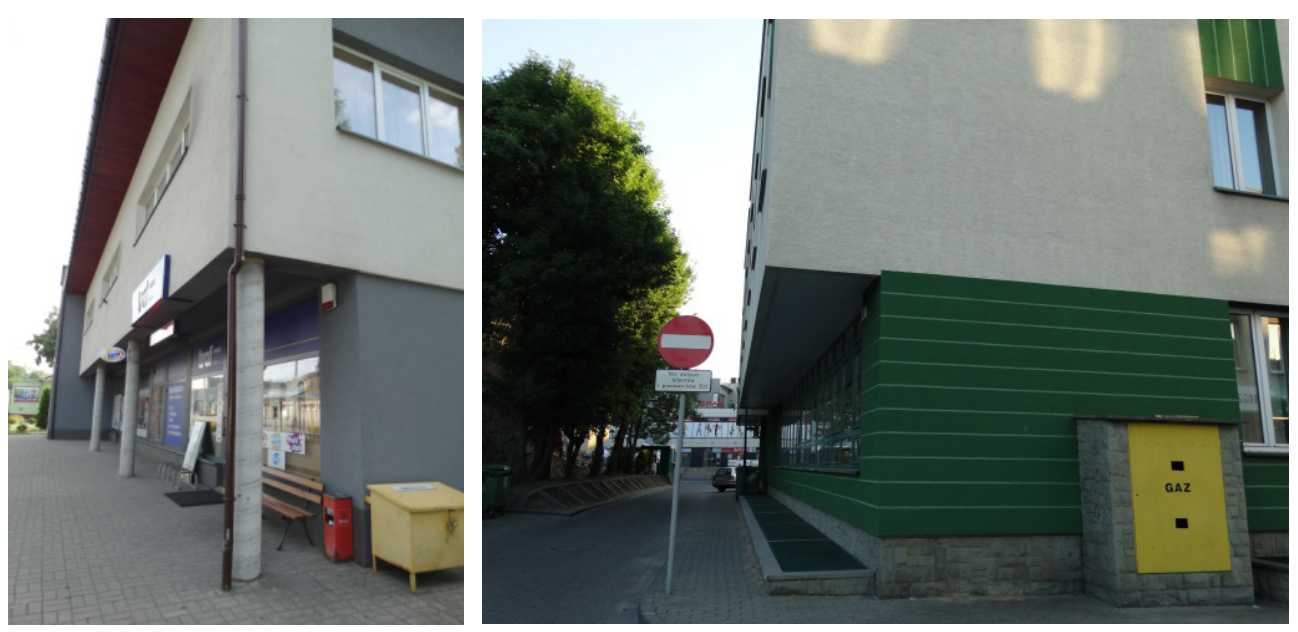

Fig. 8. Buildings with overhangs: supported and not supported by pillars (phot. M. Buśko)

A certain variation from the above-described use of pillars in construction will be such a building that is entirely constructed on pillars. This is not a frequent case, but it may happen in practice - an example is illustrated in Figure 9. In this building, neither the foundation wall nor any external walls intersect the surface of the ground. With respect to the definition of the contour, this case is specific and should be considered separately.

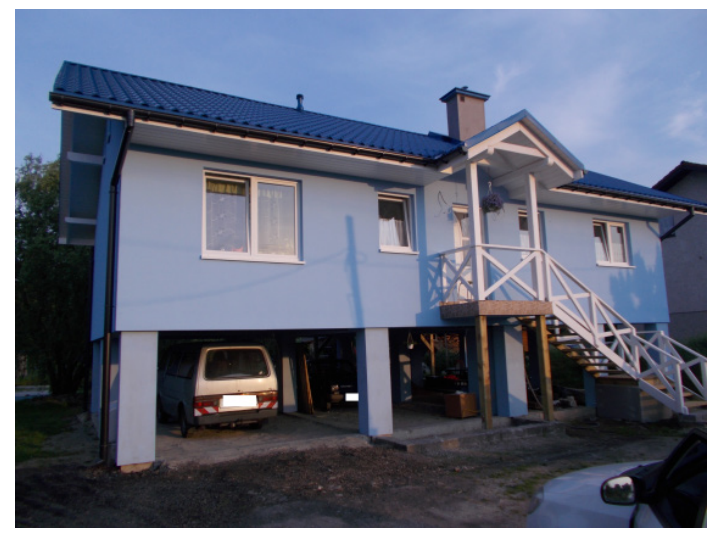

Fig. 9. A building entirely constructed on pillars (phot. M. Buśko)

If the roof is supported by pillars, the recommendation that the contour is defined by the outer edges of the roof $(\S 63.1 \mathrm{~b}$ - introduced in 2015 during another amendment to the regulation on the Register of Land and Buildings) can be described as a very unfortunately formulated provision in the legislation currently in force in Poland - examples are depicted in Figure 10. 

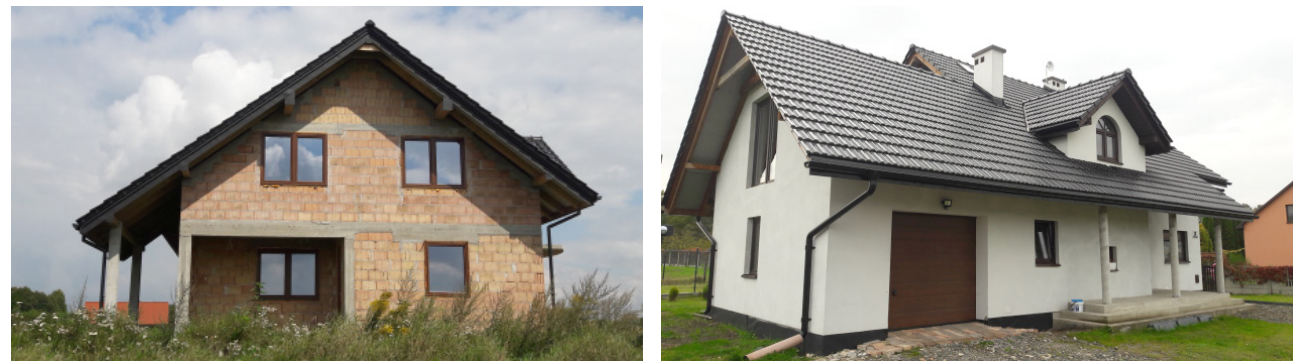

Fig. 10. Buildings in which roofs are supported by pillars (phot. M. Buśko)

By literally applying the legal provisions (and this would be an ideal case from the point of view of the rule of law in the country), it should be emphasized that such a provision states that architectural solutions that introduce pillars as supports of extended roofs of buildings necessitate defining the contour of a building according to the outer edges of the roof. Just as is the case with overhangs supported or not supported by pillars, this is detrimental to the uniformity and harmonization of the data in the cadastral database of buildings and other registers (as demonstrated in [3]). Examples of various surveying solutions in this respect are provided in [10]. Unfortunately, none of the interpretations presented there are able to withstand criticism, because there is no clear solution in the current legal status on how to present the contour of a building in the architectural form as illustrated in Figure 10. An additional problem is that, in most buildings, there are gutters installed around the roof that obscure the corners of the roof, making it impossible to measure with the required accuracy (Fig. 11).
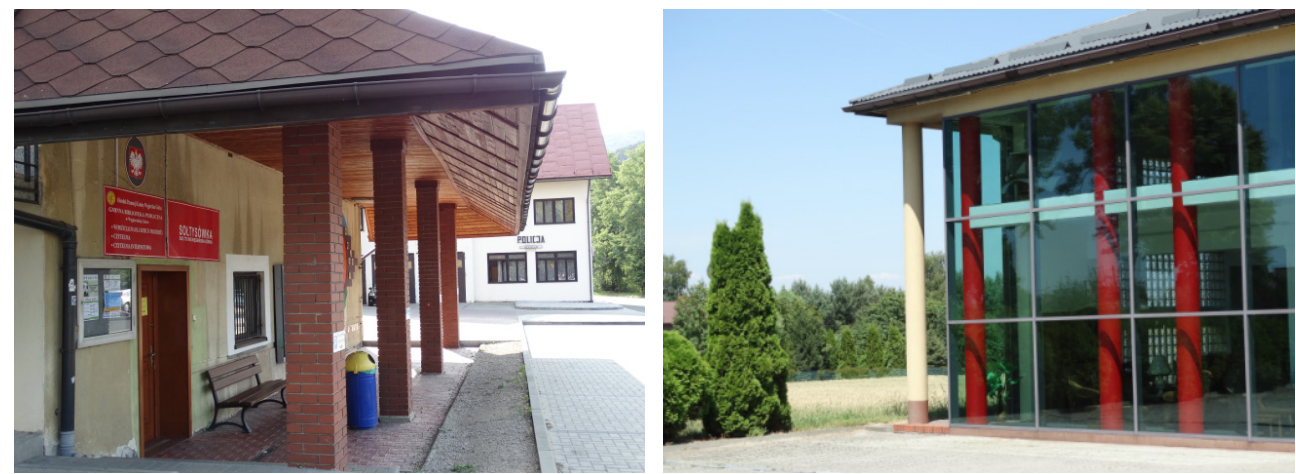

Fig. 11. Gutters obscuring turn points of roof (phot. M. Buśko)

It might be presumed that, by introducing the provision on the roof determining the contour of a building structure in 2015, the legislator had a specific type of a building structure in mind, such as a pavilion. In the Polish Classification of Types of Construction [24] (which the current Register of Land and Buildings refers 
to as regards the definition of a building), pavilions are considered to be buildings (Fig. 12). And, in certain situations that the legislator specifies in \$78.3.4 of the Register of Land and Buildings, they are entered into the real estate cadastre [9]. However, if that was the legislator's objective, it was not met whatsoever. At the same time, a lot of confusion and great chaos was caused among ordinary buildings whose roofs were supported by pillars in some places. For this reason, it is necessary to amend the law in this respect.
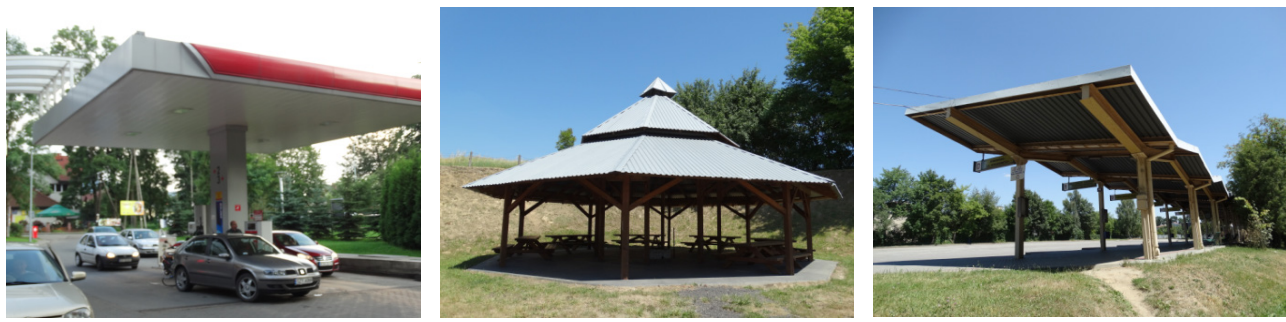

Fig. 12. Pavilions as specific types of buildings in Polish legislation (phot. M. Buśko)

The contour of a building is inseparable from the development area of a building. Table 1 contains a definition of the development area of a building that generally results from its contour but is defined slightly differently in each version of the regulation.

Based on the examples discussed here, the proposed definitions of the contour of a building and of the development area will be presented in the next chapter to eliminate the above-mentioned defects.

\section{Discussion}

\subsection{Proposed Definitions of Contour of Building and Development Area}

An amendment to the Register of Land and Buildings put into effect in 2013 introduced a number of detrimental provisions regarding buildings. The illegibility of the content of the provisions, disorder, and often a lack of mere logic in their formulation made it necessary to interpret the law rather than to use it. Chaos, inconsistencies in interpretation, and qualification of field details in buildings occurred. The scope of the attributes required by the provisions of the regulation for a building to be entered into the database became enormous. Of course, this turned out to be unrealistic in practice, given surveyors inability to capture much of this cadastral data during geodetic surveys or field inspection.

Another amendment to the regulation introduced in 2015 eliminated certain errors (for example, private pavilions that are parts of households were removed 
from the real estate cadastre); however, it redefined the contour of a building at the same time, extending it to the outer edges of the roof if the roof was supported by pillars. This record must be absolutely changed and placed in its revised wording in a separate subsection so it is clear that it refers to pavilions only.

To sum up the above considerations, the author tried to regulate the definition of the contour of a building. Before attempting to formulate the definition of the contour, it is necessary to specify which elements of a building should be included. At the same time, what is to be understood by the development area of a building should be defined as a very important indicator in correlating the data contained in the real estate cadastre and the construction industry as well as spatial planning and development. For this correlation and interoperability of the cadastral data with other industries, the author believes that the contour of a building should include its "ground floor," while the development area should cover both the contour and the overhangs, which are blocks of a building structure (regardless of whether they are supported by pillars or not). After numerous analyses carried out in several of the author's studies and conference speeches, she suggests that the proposed definition of the contour of a building contained in the real estate cadastre should be as follows:

$\S 63$. 2. The contour of a building structure referred to in Section 1, Clause 3 shall be as follows:

2a. If the foundation or cellar walls of a building structure intersect with the surface of the ground, the contour of this building structure shall be a closed line defined by a rectangular projection of these foundation or cellar walls onto the horizontal plane.

$2 \mathbf{b}$. If the foundation or cellar walls of a building structure are not visible, the contour of this building structure shall be a closed line defined by a rectangular projection of the line of intersection of the lowest outer edges of the building's walls with the surface of the ground onto the horizontal plane.

2c. If a building is entirely constructed on pillars only, the contour of the building structure shall be a closed line defined by a rectangular projection of the lowest outer edges of the building's walls that are based on these pillars onto the horizontal plane.

2d. In the case of a specific type of a building structure such as a pavilion, the contour of this building structure shall be a line defined by a rectangular projection of the outer edges of the roof onto the horizontal plane in order to be entered into the database of the real estate cadastre.

2e. In the case of building structures with underground floors only, the contour of this building structure shall be a closed line defined by a rectangular projection of its outer edges onto the horizontal plane.

2f. If, in a multi-story building, the rectangular projections of some of its stories onto the horizontal plane are not consistent with the contour, or if neighboring buildings are connected by skyways or subways, these parts of a building that 
extend beyond the contour or are connections are distinguished in the cadastral database as blocks of a building structure using a numerical description.

3. The development area of a building structure is the surface area of a geometric figure defined by its contour referred to in Sections $2 \mathrm{a}-2 \mathrm{~d}$ along with the area of a geometric figure defined by its blocks referred to in Section $2 \mathrm{f}$ (if applicable).

\section{Summary}

Today, there is so much discussion about the legal system in Poland that it should better serve its citizens. While bringing up the issue of how necessary it is for both legal provisions and legal acts to be formulated using the language that is easily understandable by these citizens, we must be aware that the definition of the contour of a building as well as other definitions contained in legal acts related to geodesy and cartography will be used primarily by surveyors and contractors. They do not have to be specialists in legal issues (and, in fact, they usually are not); therefore, the provisions in the legislation on surveying should be as simple and transparent as possible. Only then will they be applicable. After all, each surveyor wants to do his/her job well and quickly, and the role of the legislator is to facilitate this task.

It is also important to precisely identify which registers will use the cadastral data of buildings and which will automatically implement the data to the real estate cadastre [2]. Harmonization of the cadastral data and its coherence should be ensured within these registers (as also emphasized in [1, 6-8]. Moreover, membership in the European Union obliges member states to harmonize their resources - including those on building structures - with regard to the spatial information within INSPIRE [29]. Development of the cadastre of buildings towards a 3D model for which the proper legal system should become the basis shall not be disregarded either [11, 14].

By introducing the proposed definition of the development area of a building, semantic coherence within the activities related to the investment process in construction will be ensured [26]. In this process, "the plot ratio" is used at the stages of planning and development, which, according to one of the interpretative methods, requires that the value of the total surface area of the building's aboveground stories be calculated along the external outline of the building [19].

\section{References}

[1] Bac-Bronowicz J., Głażewski A., Liberadzki P., Wilczyńska I.: Harmonizacja modeli pojęciowych BDOT10k i BDOT500 w kontekście wymiany danych. Roczniki Geomatyki, t. 13, z. 4(70), 2015, pp. 295-305.

[2] Bieda A., Hanus P.: Real Estate Boundaries on Maps for Projects. Geomatics and Environmental Engineering, vol. 4, no. 3, 2010, pp. 13-18. 
[3] Buśko M.: Analiza wpływu zmian przepisów prawa dotyczacych budynków $w$ aspekcie aktualizacji bazy danych katastru nieruchomości. Infrastruktura i Ekologia Terenów Wiejskich [Infrastructure and Ecology of Rural Areas], nr II/1, 2016, pp. 395-410.

[4] Buśko M.: Budynki w katastrze nieruchomości - atrybuty, pomiar, wymiana danych ewidencyjnych. [in:] Krakowskie spotkania z INSPIRE: europejskie i krajowe aspekty katastru nieruchomości: XI ogólnopolskie sympozjum: Kraków, 11-12 maja 2015, INSPIRE, Urząd Miasta Krakowa, Kraków 2015, [on-line:] http://inspire.krakow.pl/materialy2015/2.Busko.pdf [access: 10.06.2015].

[5] Buśko M.: Building contour line in the database of the real estate cadastre in Poland pursuant to applicable laws. EconTechMod: An International Quarterly Journal on Economics in Technology, New Technologies and Modelling Processes, vol. 5, no. 3, 2016, pp. 183-190.

[6] Głażewski A.: Analiza spójności modeli pojęciowych polskich urzędowych baz danych referencyjnych. Roczniki Geomatyki, t. 7, z. 5(35), 2009, pp. 55-77.

[7] Głażewski A.: Na drodze harmonizacji - cechy strukturalne modeli obiektów topograficznych wykorzystanych w bazach danych referencyjnych. Roczniki Geomatyki, t. 14, z. 5(75), 2016, pp. 573-582.

[8] Gotlib D.: Analiza różnic pomiędzy modelami danych BDOT10K a TBD. Roczniki Geomatyki, t. 13, z. 4(70), 2015, pp. 321-334.

[9] Hanus P., Benduch P., Pęska-Siwik A.: Budynek czy nie budynek, czyli co ujawniamy w bazie EGiB. Przegląd Geodezyjny, R. 89, nr 6, 2017, pp. 10-13.

[10] Hanus P., Benduch P., Pęska-Siwik A.: Budynek na mapie ewidencyjnej, kontur budynku i bloki budynku. Przegląd Geodezyjny, R. 89, nr 7, 2017, pp. 15-20.

[11] Jazayeri I., Rajabifard A., Kalantari M.: A geometric and semantic evaluation of 3D data sourcing methods for land and property information. Land Use Policy, vol. 36, 2014, pp. 219-230, DOI: 10.1016/j.landusepol.2013.08.004 [access:12.09.2017].

[12] Krzyżek R.: Modyfikacja wspótrzędnych naroży budynku wyznaczonego w trybie RTN GNSS z zastosowaniem algorytmu środka ciężkości NPSc2. Przegląd Geodezyjny, R. 87, nr 12, 2015, pp. 13-17.

[13] Michalik A., Załuski D., Zwirowicz-Rutkowska A.: Rozważania nad intensywnościa zabudowy w kontekście praktyki urbanistycznej oraz potencjału technologii GIS. Roczniki Geomatyki, t. 13, z. 2 (68), 2015, pp. 133-145.

[14] Paasch J.M., Paulsson J., Navratil G., Vucic N., Kitsakis D., Karabin M., El-Mekawy M.: Building a modern cadastre: legal issues in describing real property in 3D. Geodetski Vestnik, vol. 60, issue 2, 2016, pp. 256-268.

[15] Pietrzak L.: Co znowu z tymi budynkami?. Przegląd Geodezyjny, nr 2, 2017, p. 28.

[16] Struś A., Brzęczek J., Mikrut S. Wybrane aspekty budowy chmury punktów ze $z$ djęć $i$ skaningu laserowego. [in:] $8^{\text {th }}$ International scientific conference in series: Innovative technologies for surveying - using in various sectors of the economy: June 7-9, 2017, Kamionka, Poland: book of abstracts, WSIE, Rzeszów 2017, pp. 107. 
[17] The Act of May 17, 1989, Geodetic and Cartographic Law. Journal of Laws of 1989 No. 30, item 163, as amended [Ustawa z dnia 17 maja 1989 r. Prawo geodezyjne i kartograficzne. Dz.U. 1989, nr 30, poz. 163].

[18] The Act of July 7, 1994, Construction Law. Journal of Laws of 1994 No. 89, item 414, as amended [Ustawa z dnia 7 lipca 1994 r. - Prawo budowlane. Dz.U. $1994 \mathrm{nr} 89$, poz. 414].

[19] The Act of March 27, 2003, on planning and spatial planning. Journal of Laws of 2003 No. 80, item. 717, as amended [Ustawa z dnia 27 marca 2003 r. o planowaniu i zagospodarowaniu przestrzennym. Dz.U. 2003, nr 80, poz. 717].

[20] The Decree of September 28, 1947, on the cadastre of land and buildings. Journal of Laws of 1947 No. 61, item 344 (repealed) [Dekret z dnia 24 września 1947 r. o katastrze gruntowym i budynkowym. Dz.U. 1947, nr 61, poz. 344].

[21] The Decree of February 2, 1955, on the registration of land and buildings. Journal of Laws 1955 No. 6, item 32 (repealed) [Dekret z dnia 2 lutego 1955 r. o ewidencji gruntów i budynków. Dz.U. 1955, nr 6, poz. 32].

[22] The Order of Ministers of Agriculture and Public Utilities of February 20, 1969, on the land register. Official Gazette of the Republic of Poland of 1969 No. 11, item 98. (repealed) [Zarządzenie Ministrów Rolnictwa i Gospodarki Komunalnej z dnia 20 lutego 1969 r. w sprawie ewidencji gruntów. M.P. 1969, nr 11, poz. 98].

[23] The Regulation of the Ministers of Spatial Management and Construction and the Ministry of Agriculture and Food Economy of December 17, 1996, on the registration of land and buildings. Journal of Laws of 1996 No. 158, item. 813 (declared abrogated) [Rozporzadzenie Ministrów Gospodarki Przestrzennej i Budownictwa oraz Rolnictwa i Gospodarki Żywnościowej z dnia 17 grudnia 1996 r. w sprawie ewidencji gruntów i budynków. Dz.U. 1996, nr 158, poz. 813].

[24] The Regulation of the Council of Ministers of December 30, 1999, on the Polish Classification of Types of Construction (PKOB). Journal of Laws of 1999 No. 112, item 1316, as amended [Rozporządzenie Rady Ministrów z dnia 30 grudnia 1999 r. w sprawie Polskiej Klasyfikacji Obiektów Budowlanych (PKOB). Dz.U. 1999 nr 112, poz. 1316].

[25] The Regulation of the Minister of Regional Development and Construction of March 29, 2001, on land and buildings register. Journal of Laws of 2001 No. 38, item 454, as amended [Rozporzadzenie Ministra Rozwoju Regionalnego i Budownictwa z dnia 29 marca 2001 r. w sprawie ewidencji gruntów i budynków. Dz.U. 2001, nr 38, poz. 454].

[26] The Regulation of the Minister of Infrastructure of August 26, 2003, on the method of setting requirements for new buildings and land in the absence of local zoning plan. Journal of Laws of 2003 No. 164, item 1588 [Rozporzadzenie Ministra Infrastruktury z dnia 26 sierpnia 2003 r. w sprawie sposobu ustalania wymagań dotyczacych nowej zabudowy i zagospodarowania terenu w przypadku braku miejscowego planu zagospodarowania przestrzennego. Dz.U. 2003, nr 164, poz. 1588]. 
[27] The Regulation of the Minister of Internal Affairs and Administration of November 9, 2011, on technical standards performing geodetic measurements and height and situational development and transmission of the results of these measurements to the national geodetic and cartographic. Journal of Laws of 2011 No. 263, item 1572 [Rozporzadzenie Ministra Spraw Wewnętrznych i Administracji z dnia 9 listopada 2011 r. w sprawie standardów technicznych wykonywania geodezyjnych pomiarów sytuacyjnych $i$ wysokościowych oraz opracowywania i przekazywania wyników tych pomiarów do państwowego zasobu geodezyjnego i kartograficznego. Dz.U. 2011, nr 263, poz. 1572.

[28] The Regulation of the Minister of Administration and Digitization of November 2, 2015, on the Database of Topographic Objects and the base map. Journal of Laws of 2015, item 2028 [Rozporzadzenie Ministra Administracji i Cyfryzacji $z$ dnia 2 listopada 2015 r. w sprawie bazy danych obiektów topograficznych oraz mapy zasadniczej. Dz.U. 2015, poz. 2028].

[29] Wróblewska K., Pachelski W.: Analiza dostosowania obowiazujacych struktur i treści danych ewidencji gruntów i budynków do wymagań INSPIRE. Roczniki Geomatyki, t. 15, z. 2(72), 2015, pp. 253-269.

\section{Analiza przepisów prawa i propozycje zmian w zakresie definicji konturu budynku w katastrze nieruchomości}

Streszczenie: $\mathrm{W}$ artykule została przeprowadzona analiza przepisów prawa związanych $\mathrm{z}$ geodezją i kartografią w zakresie budynków ujawnianych $\mathrm{w}$ bazie danych katastru nieruchomości. Szczególną uwagę poświęcono konturowi budynku w bazie ewidencji gruntów i budynków oraz jednemu z atrybutów opisowych budynku, jakim jest pole powierzchni zabudowy. W aktualnych przepisach prawa pole powierzchni zabudowy wynika wprost z konturu budynku.

Tezą artykułu jest stwierdzenie, że aktualny sposób definiowania konturu budynku oraz wynikającej z niego powierzchni zabudowy nie oddaje postaci, jaką budynek faktycznie przyjmuje w terenie. $W$ celu weryfikacji powyższej tezy przytoczono przykłady różnorodnych budynków. Przykłady te uwidaczniają mankamenty $\mathrm{w}$ definicjach, co z kolei powoduje niejednolitość danych ewidencyjnych w bazie katastru nieruchomości w skali Polski. Skutkiem błędów w aktualnie obowiązujących definicjach są również ograniczone możliwości wykorzystywania danych katastru nieruchomości podczas zadań związanych z planowaniem gospodarczym, planowaniem przestrzennym oraz wymiarem podatków i świadczeń.

Na podstawie analizy aktualnych aktów prawnych oraz przykładów budynków występujących $\mathrm{w}$ terenie $\mathrm{w}$ artykule sformułowano propozycje definicji konturu budynku oraz powierzchni zabudowy budynku.

\section{Słowa}

kluczowe: budynek, kataster nieruchomości, ewidencja budynków, kontur budynku, powierzchnia zabudowy, dane przestrzenne 